\title{
Pitting Non-Relative Cluster Foster Care Placements Against the Best Interests of the Child
}

\author{
Prof. S. M Kang'ethe \\ University of Fort Hare. Department of Social Work and Social Development \\ Private bag X1314, ALICE. 5700, South Africa \\ Email: skangethe@ufh.ac.za \\ Miss Kausi Nyasha
}

Masters of Social Work Student, University of Fort Hare, P/B X1314 Alice, 5700

Email: 200909668@ufh.ac.za

Doi:10.5901/mjss.2014.v5n14p554

\section{Abstract}

Globally, regionally, nationally and locally, foster care placement remains a practice that is mired in controversy and complexity, specifically with regards to its implication upon the total wellbeing of the child and the effectiveness of such placement in meeting the best interest of the child. South Africa is regarded as the leading nation with the premier dominance of children in need of care and protection in Southern Africa and is regarded as a guru in championing and promoting child custody within foster care placements. Accordingly, this paper through a systematic review of literature pitted the perfidy and panacea of foster care against the best interest of the child in South Africa. The paper also recommends the child welfare system to contemplate promoting and advising immediate families to take the responsibility of caring and protecting those children in need of care and protection. Likewise, the paper also indorses the need to support and monitor the functioning of non-relative foster care placements so that they adhere to the requirements on the best interest of the child.

Keywords: Foster care, child in need of care and protection, children's rights, family care, parental care, and alternative care, children's act no 38 of 2005.

\section{Problem Statement}

In recent times, non-relative cluster foster care placements have increasingly been facing a barrage of discontentment and disapproval specifically with regards to its ability to meet the best interest of the child. Literature continues to hold that some adoptees in cross racial foster care placements may not be happy as the environments lacks several factors that define the best interests of the child. More so, fostered children are treated as social- illegitimate beings simply because of their erstwhile life upheavals of neglect, abandonment, orphaned or abuse. Nonetheless, the duty of any society is to offer care and protection to vulnerable children while still upholding the notion of the best interest of those children. This applies also to foster care placements which is at the apex of child custody in South Africa. However, empirical evidence denotes that non-relative cluster foster care placements in South Africa are lacking the ethical and moral fibre to fulfil the conditions of the best interest of the child. They therefore attract an exploration and scrutiny to validate such allegations and suspicion. Accordingly, there is an allegation and suspicion that the total well-being of the fostered children is being caught in between fixation and progression. More-so, empirical evidence shows that there is very little research that reports this phenomenon in South Africa. Henceforth, a need exists to pit foster care placements against the inventory factors that define the best interest of the child within the South African context.

\section{Introduction and Background}

Globally, regionally, nationally and locally, cluster-foster care placement has been receiving wide debates and discourses specifically with regards to its implication upon the total wellbeing of the child and its effectiveness in meeting the best interest of the child (Moos and Mwaba, 2007). This issue is very worrying across South Africa with its high rate of children in need of care and protection and where foster care placements have been entrusted to provide an ideal source of custody for these vulnerable children (Moos and Mwaba, 2007; Gebel 1996). In other words, foster care placements have 
been regarded as the utmost, readily available haven for children in need of care and protection. Accordingly, South Africa is considered as the leading nation in championing and promoting child custody within foster care placements.

Nevertheless, much empirical evidence shows that fostered children do have diverse life experiences within their foster care placements that impact much on the concept of best interest of the child as laid down the United Nations Convention on the Rights of the Child (UNCRC) (1989). The Convention on the Rights of the Child sets out the rights that must be realized for children to develop their full potential, free from hunger, want, neglect and abuse. The Convention describes children as human beings and as the subject of their own rights. The Convention also offers a vision of the child as an individual and as a member of a family, with rights and responsibilities appropriate to his or her age and stage of development. Thus, the Convention and its acceptance by many countries including South Africa has heightened recognition of the fundamental human dignity of all children and the urgency of ensuring their well-being and development together with there best interest as the major concern. Moreso, the Convention makes clear the idea that a basic quality of life should be the right of all children, rather than a privilege enjoyed by a few. By recognizing children's rights in this way, the non-relative cluster foster care placement seem to raise more arguments amongst vast academic gurus with many questioning the effectiveness of such kind of placement in meeting the interest of the child.

Despite the efforts of having children to be in a family environment in this case the non-relative cluster foster, many children in these placements suffer from deprived attachment or bonding to parent figure, indirect neglect, unequal access to parental guidance, and also lack affectation and love only to cite a few examples. These are problems that occur in both industrialized and developing countries including South Africa with its high rate of children in need of care and protection and with foster care as the major care option. Subsequently, South Africa is faced with a predicament of wanting to comply with the stipulations of the 1989 United Nations convention specifically upholding the best interest of the child and at the same time ignoring the entire psycho-social quagmire attached to cluster foster care placements. Hence, the researchers seek to bring to the fore this psycho-social quandary through pitting non-relative cluster foster care placements against the best interest of the fostered child in South Africa. However, what is of paramount concern is exploring whether the so-called child haven (non-relative cluster foster care placements) are in line with the best interest of the child; and if not to what extent. This could possibly unearth underpinning factors that can be worked on to ensure that the best interests of the child are factored in these fostered care placements. This paper, therefore, will make an attempt to strike a debate on non-relative foster care placements against the best interest of the child.

\section{Operational Definition}

\subsection{The best interests of the child}

Although there is no standard definition of the best interests of the child, in this paper, the term generally refers to the deliberation that courts undertake when deciding what type of services, actions and orders will best serve a child as well as who is best suited to take care of a child. The term largely fulfils the factors laid down in the 1989 United Nations Conventions on the right of children.

\subsection{Child}

The general definition of a child under the South African constitution is a person under the age of 18 . However, this study will also accommodate Section 176 of the Children's Act 38 of 2005 which states that a person may, for academic reasons, remain in foster care beyond the age of 18 and yet not above the age of 21 . Thus, persons who still remain in foster care older than 18 and younger than 21 will be defined as children in this study.

\subsection{Foster care}

This refers to a substitute care for a planned period of time for a child when his/her own family cannot provide or care for a temporary or extended period of time. In South Africa, this refers to a statutory arrangement made in terms of the Children's Act 38 of 2005 and/or 41 of 2007 for the custody of a child in need of care and protection when the immediate family custody fails.

\subsection{Child in need of care and protection}

In this paper, this refers to a child who does not have a home or shelter and no means to obtain such an abode. 


\subsection{Cluster foster care placement}

This refers to the custody of more than one foster child to six foster children by one foster parent.

\subsection{Non relative cluster foster care placements}

In this paper this refers to a form of child care in which at least two to six children are placed in the care on a parent who is not related to the children.

\section{Methodology}

This article is a discourse one eliciting debates largely surrounding the foster care placements on the best interest of the child. In-addition, the article has borrowed from journals, government publications, intuitive as well as experiences of the researchers in the field of child care and protection.

\section{Conceptualizing the Concept of the Best Interest of the Child}

According to James (2004), the notion of the best interests of the child is the most important factor all children's courts must consider in making any decision regarding a child. Likewise, in South Africa as long ago as 1969, the standard of the child's best interests was labelled by the children's courts as a golden thread which runs throughout the whole fabric of any law relating to the custody of children (Department of Social Development Annual Report, 2012). At present, South Africa has a constitution which governs the best interests of the child and this is constitutionalised in section 28(2) of the same Constitution. According to this constitution, the child's best interests are of paramount importance in every matter concerning the child. Consequently, the Convention on the Rights of the Child also interpolates the best interests of a child as of high primacy in any decision that affects the child especially when comes to child care and protection (United Nations Conventions on the rights of children (UNCRC), 1989; Organization of African Unity (OAU), 1990). In other words, this international instrument has been welcomed as a comprehensive treaty on the rights of the child and the most universally accepted human rights document in history (UNCRC, 1989). Likewise, the Convention places children at the epicentre of the spread of human rights generally and has been ratified by vast countries. As a result, South Africa became a signatory to the Convention on 29 January 1993 and ratified the Convention Berrick and Shlonsky, 2001). Thus, this entails that South Africa must conform to the obligations on the Convention and the best interest of the child forms one of the pivotal foundation stones of the Convention with much emphasis that children are entitled to special care and assistance. In South Africa, the best interests and welfare of the child are determined by the court's consideration and evaluation of all factors affecting the best interests and welfare of the child (Freeman and Nkomo, 2006).

\section{Pitting Non-Relative Cluster Foster Care Placements Against the Best Interest of the Child in the South African Context}

\subsection{Non relative Foster care placements embrace gaps in child care}

Though some noteworthy acclaims can be awarded to the non-relative foster care placements, there is an enormous dark cloud that insulate such approvals. These researchers contend that within the ambit of the South Africa's child care system, foster care is normally considered one of the most ideal form of alternative care for children in need of care and protection (Snyder, 2012). To this end, many thousands of South African children have benefitted from court-ordered foster care (James 2004). However, it should be succinctly clear that the family is normally the environment most suited to the healthy growth and development of the child Snyder, 2012). Parents have a natural, legal, and moral right, as well as a duty to care for and support their children. To that end, it is presumed that the best interests of a child are ordinarily served by leaving the child in the custody of the parents, who are expected to have the strongest bond of love and affection and to be best able to provide a child those needed qualities that make a child's life safe and secure (Freeman and Nkomo, 2006).

\subsection{Diminished opportunities for foster care placements in South Africa}

Much as cluster foster care placements can be a panacea to solving the problem of children in need of care in South 
Africa, the domain of child care especially the Department of Child welfare is at crossroad. This is because of the unavailability of families to volunteer to take care of children in need of care. This therefore, is increasing $g$ doubt of whether this form of care as provided for in the Child Care Act of 1983 can adequately deal with the demands of the best interest of the child. For example at present, there are approximately 60000 children in court-ordered foster care in South Africa and social workers are having difficulties in finding sufficient foster families (Snyder, 2012). It is estimated that nine out of ten families will need to take in a child unrelated to them in order to cope with the sheer number of children in need of care and protection (Snyder, 2012). With this challenge, then the non-relative cluster foster care placement becomes an ideal option. This is a most improbable scenario and one which would not be suitable for all the children concerned specifically in meeting the best interest of these children. According to James (2004) the non-relative cluster foster care placements are regarded as perfidious to the total well-being of the child as well as jeopardising the best interest of the fostered children.

\subsection{Reduced attachment for cluster foster cares on fostered children}

According to Freeman \& Nkomo (2006) and James (2004) non-relative relative foster parents are usually less emotionally prepared than other foster parents to nature and help the fostered children to heal quickly from emotional injury. Nevertheless, the loss of a parent or parents, whether or not they provide a level of care that meets the state's minimum standard, is likely to cause significant trauma to a child. In-addition, since child is more likely to be less familiar with a non-relative caregiver, many experts within the field of child care and protection suggests that these placements are even more traumatic and disruptive for a child which is against the best interest of the child. According to Berrick and Shlonsky (2001), placing a child within the non-relative cluster foster care homes may reduce the capacity to offset some of the psychic trauma the child was subjected to before removed from his/ her primary source of custody.

Non-relative foster care placements tend to lack the ability to offer the close bond of love and affection to the all the fostered children and this also reduce the foster parents' awareness and detection of any form of deviance upon a child. When placed within non-relative cluster foster care families, children are meagre likely to have their emotional, spiritual, and nurturance needs met which is also against the best interest of the child. Accordingly, children in non-relative cluster foster care placements exhibit a greater degree of physical, behavioural and emotional problems than other children (James (2004). Most children who enter into non-relative foster care have once been subjected to dire experiences of abuse or neglect and separation from a parent. These traumatic experiences can lead to a variety of behavioural and emotional problems including severe attachment disorders (Hughes 1999; Bowlby 1973, 1980). These factors can also contribute to a greater likelihood of poor child well-being, further compromising the healthy development of an already vulnerable group of children (Duncan and Brooks-Gunn 2000). Children with poor psychological or physical well-being present challenges not only to their non-relative foster care parents but also to their future lives. Repeatedly it has been shown that many of these children suffer from psychological, health, and educational deficits or delays (Zima et al 2000). Empirical evidence shows that when comparing children in non-relative foster care placements with other children in other forms of foster care on these measures of well-being, the former group of foster children have more difficulties (Bilaver et al 1999). All these connotations of non-relative foster care placements are in-contrary with the best interest if the child.

\subsection{Lack of continuity of primary family identity}

Accordingly, other disadvantages of placing children within the non-relative which also jeopardise the best interest of the child include: lack of continuity of family identity; restricted access to relatives including birthparents and siblings; deprived of an on-going life within the ethnic, religious, and racial community of origin and familiarity for the child based on pre-existing relationships between the child and caregiver (James 2004). Also, the non-relative foster care placement poses a huge problem of drift and instability upon fostered children. James (2004) stated that children with a higher number of placement changes are known to experience a decreased likelihood of reunification, greater severity of behavioural difficulties. More-so, once discharged from non-relative foster care, children are more likely to re-enter foster care than children any other placed. All these have been noted by the researchers as being in contrary with the best interest of the child.

The relationship between the child and the primary family is contextualised in the best interest of the child stating that the family is the essential group in any society and the natural environment for the growth and well-being of all its children. More-so, it further recognises that children should grow up in a family environment, in an atmosphere of happiness, love and understanding (James 2004). Likewise, the best interest of the child refers to the right of children to 
be cared for by their parents at first instance. Children are primarily dependent on those closest to them in this case their immediate family. The family therefore has the primary responsibility to provide for the rights of their own children. This is also evident from article 18(1) of the Convention on the Rights of the child which accords parents and legal guardians the primary responsibility for the upbringing and development of children and provides that the best interests of children will be the basic concern of the parents or legal guardians. Nevertheless, the non-relative cluster foster care placements are being challenged here since this is a scarce aspect within the realm of such placements as a result, this form of child custody is deemed to be an antagonist to the best interest of the child.

\subsection{Diminishes the well-being and development of the fostered children}

Another detrimental effect of non-relative cluster foster care placements against the best interest of the child is attributed to the capabilities of these placements in damaging the well-being and development of the fostered children. Empirical evidence reveals that fostered children in non-relative foster care placements do experience diverse psycho-social dilemmas which include; trust vs. mistrust; autonomy vs. shame and doubt; initiative vs. guilt; industry vs. inferiority; identity vs. role confusion; intimacy vs. isolation; generativity vs. stagnation; ego integrity vs. despair loss of attachment and also (Erikson,1968). Likewise, Cook and Cook (2005) noted that non-relative cluster foster care placements can confuse the child by shifting him/her between two different worlds thereby damaging the child's behaviour. As noted by most behaviourists behaviour emanates as a response to a stimulus. According to Wrench (2008) non-relative cluster foster care placements are the most undesirable source of child care and this perpetuate the undesirable life experiences in which children have been subjected to before being adopted. More-so, James (2004) argues that non-relative are not well equipped to provide proper nurturing to fostered children to be good parents in the future who are not abusive even to the generations to come.

\section{Theoretical Framework}

This paper is guided by two theories that is, the psycho-social theory and the attachment theory.

\subsection{Psycho-social theory}

The psycho-social theory was propounded by Erik Erikson (1968). The theory focuses on explaining developments that takes place in social relationships and self-understanding over the life span of an individual. The psychosocial theory denotes that every human being experience eight psychosocial crisis stages which ominously affect their development and personality. The theory refers to the complications which happen at each human developmental stage as psychosocial crises (Erikson 1968). Accordingly, this concept was borrowed from the work of Freud's psychoanalytic theory which defines crisis as an inner struggle by which every human being must confront and deal with so as to develop and grow efficaciously. Likewise, all the unresolved conflicts have massive distortions upon an individual life (Erikson 1968). Psycho-social theory is imperative in this paper as it address psycho-social experiences of fostered children. These, are as follows: trust vs. mistrust; autonomy vs. shame and doubt; initiative vs. guilt; industry vs. inferiority; identity vs. role confusion; intimacy vs. isolation; generativity vs. stagnation and lastly ego integrity vs. despair. Accordingly, all these are in dire conflict with the best interest of the child.

\subsection{Attachment Theory}

The theory of attachment was originally developed by John Bowlby (1907-1990), a British psychoanalyst who was attempting to understand the intense distress experienced by infants who had been separated from their parents (cited in (McLeod 2007).The theory further postulates on the behaviors children are likely to exhibit as a result of the loss of a caregiver and the nature of the relationship the cross racial family faces. Within the attachment theory, the term attachment is used to describe the dependency relationship a child develops towards his or her primary caregiver Bowlby (1907-1990) in Hardy, 2007). Hence, this theory is applicable in this study as it attempts to expound on the aspects of separation and loss experienced by fostered children. 


\section{Way Forward}

\subsection{Advocating for the primary family child custody}

Although the role of non-relative foster care cannot be overemphasized especially in considering the ever increasing rate of children in need of care and protection in South Africa, these researchers are of the contention that the primary family need to take the priority of child custody (WHO 2002 and Gebel 1996). This implies that care within the family takes priority over the non-relative foster care placements. Such an option is not only better for the child's best interest rather it also helps attain the total well-being of the same child.

\subsection{Supporting and monitoring of the non-relative foster care placements}

Cuddeback \& Orme (2002) suggest that, for non-relative cluster foster care placements to provide quality care that meets the children's needs as well as the best interest of the child, certain elements must be in place. These elements according to him include, support and constant monitoring. These researchers, therefore, recommends to government, and NGOs to support and monitor the functioning of non-relative cluster foster care placements.

\section{Conclusion}

Conclusively, this paper has pitted the non-relative cluster foster care placements against the best interest of the child and a conclusion has been drawn that this type of child care has more demerits than merits. Not only has this paper identified the non-relative foster care as being antagonistic to the best interest of the child but, also the total wellbeing of the same child. Lastly, the paper emphasises the need for care of children within their immediate families since a family is regarded as the most ideal source of child psycho-social nurturing. The paper also recommends continual support and monitoring of these non-relative foster care placements in order for them to be able to adhere to the stipulations on the best interest of the child.

\section{References}

Cook, J. L., \& Cook, G., (2005). Child Development: Principles and Perspectives.Boston: Allyn and Bacon. Department of Social Development (DSD) Annual Report (2012) at www.dsd.gov.za (Accessed June 23, 2013)

Freeman, M \& Nkomo, N. (2006): Guardianship of orphans and vulnerable children. A survey of current and prospective South African caregivers. AIDS Care: Psychological and Socio-medical Aspects of AIDS/HIV, 18:4, 302-310

Lyons, T. Hardy. (2007). Attachment Theory and Reactive Attachment Disorder: Theoretical Perspectives and Treatment Implications. California: Sage.

Snyder, C.R., (2012). 'Building Kinship and Community: Relational Process of Bicultural Identity Among Adult Multi-racial Adoptees.' Family Process 49 (1): 26-42.

Wrench, J. (2008). A Gestalt Perspective on the Experience of Being Adopted as a child: Recommended Guidelines for Post-adoption support and Therapy (Unpublished Thesis) Pretoria: University of South Africa.

Berrick, J.D. \& Shlonsky, A.R. (2001). Assessing and promoting quality in kin and Non-kin foster care. Social Service Review, 37, 60-83.

Cuddeback, G.S. \& Orme, J.G. (2002). Training and services for kinship and nonkinship foster families. Child Welfare, 81, 879-909.

Gebel, T.J. (1996). Kinship care and non-relative family foster care: A comparison of caregiver attributes and attitudes. Child Welfare, 75, 5-18.

Hegar, R.L. \& Scannapieco, M. (2002). Kinship care providers: Designing an array of supportive services. Child and Adolescent Social Work Journal, 19, p.315-327

James, S. (2004). Why do foster care placements disrupt? An investigation of reasons for placement change in foster care. Social Service Review, 12, 601-627.

UNCRC (1989).Conventions on the rights of children. Adopted by the general Assembly of the United Nations on $20^{\text {th }}$ November 1989.

OAU (1990). African charter on the rights and welfare of the child.OAU.doc.

CAB/LEG/24.9/49.1990 